\title{
Epithelial Membrane Protein 1
}

National Cancer Institute

\section{Source}

National Cancer Institute. Epithelial Membrane Protein 1. NCI Thesaurus. Code C17979.

Epithelial membrane protein 1 (157 aa, $18 \mathrm{kDa}$ ) is encoded by the human EMP1 gene.

This protein is involved in cell growth and proliferation. 